BERDE Csaba - MÓRÉ Mariann

\title{
A MUNKAVÁLLALÓI TUDÁS HASZNOSÍTÁSÁNAK ÚJ LEHETŐSÉGE FELSŐOKTATÁSI KERETEK KÖZÖTT
}

A szerzók tanulmányukban áttekintést kívánnak adni az elôzetes tudás, a munkahelyi tanulás és a tudás felsốoktatási keretekben való elismeréséról. Céljuk az, hogy ráirányítsák a szervezetek figyelmét egy olyan törvény által biztosított lehetôségre, amelynek bevezetése érdeke a munkaeró-piaci szereplóknek is. Hazánkban az egyetemek/fóiskolák még csak ismerkednek az elózetes tudás elismerésének elveivel, de a kutatások szerint nagyon gyenge az érdekeltségük. Ez a megközelítés változhat, ha a szervezetek, a szakmai kamarák megfogalmazzák a tudáselismerés iránti igényüket, s ezzel felgyorsítják a törvény által már biztosított validáció széles körú elterjedését.

\section{Kulcsszavak: tudás, munkahelyi tanulás, validáció}

A XXI. század globalizált világa olyan kihívások elé állította a munkáltatókat és a munkavállalókat, amelynek eredményeként megváltoztak a tudással kapcsolatos elvárások. A szervezetek új ismeretek birtoklását, képességek és kompetenciák meglétét várják el a munkavállalóktól, s ezeket a hagyományos iskolai keretek között csak korlátozottan lehet megszerezni. Ennek eredményeként a formális kereteken kívüli tudástöbblet legalább annyira szükséges, és legalább annyi haszonnal bír az egyének életében, mint az iskolai tudásszerzés. Ez az új megközelítés új szerepben jeleníti meg a tudás fogalmát, meghatározása új elemekkel bővül. A tudás több ezer éves történetéből az a következtetés vonható le, hogy a tudás egy törekvés, amely a világ megismerésére szolgál (Benedek, 1994). A filozófia oldaláról közelítve a fogalomhoz (Polányi, 1994) állíthatjuk, az ember lényegesen többet tud annál, mint amit a kommunikáció során közölni képes. Polányi Mihály értelmezésében a tudás egy része rejtve marad, ún. hallgatólagos (tacit) tudás, hiszen minden tevékenységi formában szert teszünk olyan ismeretekre, amelyek beazonosítása kívül esik a tudatosság határain. A hallgatólagos tudás szavakkal alig megfogalmazható, sok esetben fel sem tudjuk idézni milyen körülmények között tettünk szert rá. A tanulmány olvasóinak egy része felidézheti a személyi számítógépek magyarországi megjelenésének éveit, amikor a használathoz, az alkalmazáshoz nem álltak rendelkezésre tanfolyamok, s ezek híján egymástól és önmagunk hibáiból, következtetéseket levonva, sajátítottuk el a szükséges ismereteket. A számítógépes prezentációk készítését sem lehet csupán könyvekből, tanfolyamokból elsajátítani, a sok gyakorlás, az új technikák alkalmazása folyamatosan fejleszti a tudást. Lengyel $\mathrm{Ba}$ lázs a hallgatólagos tudás körébe sorolja az egyetemek doktori iskolájában folyó tudományos tevékenység egy részét (Lengyel, 2004). Egyetérthetünk Lengyel megállapításával, hiszen a kutatás módszertana, a számítógépes kutatási módszerek alkalmazása a kurzusok során és a szakirodalomból megtanulható, de a személyes interjúk lefolytatásához elengedhetetlen helyes viselkedés, az etikus kutatói magatartás már csak a témavezetô személyes példamutatása alapján sajátítható el. Ugyanez a folyamat érvényesülhet a munkahelyeken, amikor egy új belépő a mentor és a kollégák magatartásának, szokásainak megfigyelése alapján sajátítja el a szervezeti kultúra néhány elemét. A tudás az oktatáselméletekben is alapfogalom. Csapó Benố meghatározása szerint az emberi tudásban az ismeretjellegú tudás és a képességjellegú tudás rendszert alkot, amelynek múködtetéséhez szükséges integráció egy sajátos emberi jelenség (Csapó, 2002). Ennek az integrációnak 
az egyik színtere az iskola, amely hosszú éveken át az egyes tudományterületek formalizált részeit oktatta. A technikai fejlődés, a számítógépek megjelenése azonban új utakat nyitott meg az ismeretszerzésben. A folyamat az iskolákat eddig ismeretlen kihívások elé állította, hiszen az informatika segítségével az előzőekkel összemérhetô, esetenként azt meghaladó mértékú tudás megszerzésének esélye jött létre. A menedzsmenttudomány a tudásra mint erőforrásra tekint, s a közgazdaságtanban régóta folyik arról a vita, hogy magán- vagy köztulajdon-e a tudás. A kérdés ilyen felvetése a tudás gazdasági jellegére utal, amellyel történô gazdálkodás egyre fontosabb tényezôvé válik a szervezetek versenyképességének megőrzésében. Erôforrásként tekintve a tudásra négy különbözô módon megszerezhető tudástípust különböztethetünk meg (Boutellier et al., 2000):

- tudás a szocializáció által (a vállalati kultúra megismerése által jön létre),

- tudás a tapasztalás által (a folyamatok megfigyelése útján és a szervezeti rutinnal jön létre),

- tudás a dokumentáció által (a szervezetben fellelhetố írásos anyagok tartalmazzák),

- tudás a termékben (az alkotás útján létrejövő, már értékesíthető tudás).

A szocializált és tapasztalati tudás hallgatólagos tudás, amelyet nehéz továbbítani, csak azok érthetik meg, akik jelen vannak a szervezetben. Ennek a tudástípusnak van szerepe a beillesztési folyamatban. A személyügyi tevékenységgel foglalkozó szakkönyvek azon része, amely a HR gyakorlati feladataival foglalkozik (Lévai - Bauer, 2004), a kiválasztás-felvétel összefüggésében határozza meg a beillesztés folyamatát. A beillesztési program általános szakasza minden új belépőt érint, és az alábbi területeken megszerezhetố tájékozottságra koncentrál: munkaidô-szabályozás, szervezeti hierarchia, munkavédelmi szabályok és munkahelyi kultúra megismertetése, találkozó a munkahelyi vezetókkel. A beillesztési program egyéni szakasza a betöltendő munkakörrel összefüggésben lévő tudás megszerzésére helyezi a hangsúlyt. A beillesztés minden esetben az információ körül forog, annak szükséglete/átadása formájában jelenik meg (Móré, 2011). Az új belépőnek információra van szüksége a munkakövetelményekról, az interperszonális hálózatról, a közvetlen munkacsoportról, a szervezeti kultúráról. A szervezet információt akar átadni, hogy az új belépốt a lehetô leghamarabb integrálja, ehhez az átadáshoz használhatja fel azt a munkahelyi közösséget, ahová az új munkatárs került. Ez az információ válik tudássá, amikor birtoklójánál cselekvést vált ki (Sveiby, 2001), amely az alkalmaz- kodásban testesül meg. A tudás különböző megközelítéseit kiegészítve szervezeti összefüggésben tudásnak határozzuk meg a szervezetben lezajló folyamatok megvalósításával kapcsolatos feldolgozott ismereteket. A tudás a változással, a fejlődéssel van összefüggésben, ezért időbeli és térbeli meghatározottsága is van. Idődimenzióját tekintve: nem szerezhetố meg csupán az élet egy szakaszában, az egyéneknek egész életükön át kell a tudásra törekedniük. Térbeli dimenzióját tekintve: formális keretek között és azon kívül is megszerezhetó, épülhet a bárhol megszerezhetô egyéni tapasztalatokra.

\section{A tudás térbeli dimenziója: tanulási utak}

A vázolt tudásmegközelítések bármelyikét nézzük, közös bennük, hogy tudásra egyfajta tanulás útján tehetünk szert, a tanulás a tudás gyarapodásához vezető folyamatot jelenti. A tanulmány a felnőttkori (munkavállalói) tanulás kérdéskörét érinti, de a megállapításainkat nehezíti, hogy a felnőttek tanulásának (adult learning) nincs egy általánosan elfogadott definíciója. Az OECD 18 országra kiterjedô vizsgálata mutatott rá arra, hogy országonként eltérố terminológiákat használnak (Mihály, 2003). Az ekkor kibontakozó vitát befolyásolta az Európai Bizottság 2000-ben kiadott „Memorandum on Life Long Learning" dokumentuma, amely a tanulásban való részvételt a végeredmény szempontjaiból is vizsgálta, és különös hangsúlyt helyezett az informális tanulásra. A szakmai diskurzus következményeként ma a tanulás szempontjából felnôttnek tekintjük azokat 18 és 64 év közötti állampolgárokat, akik befejezték a kötelezó oktatás szakaszát. Tanulásnak tekintjük azt a tevékenységet, amely a felnôttek esetében az alábbi szempontok valamelyikét magában hordozza: formális, nonformális vagy informális keretekben folyik, és megállapítható, hogy abból mit tanul a felnôtt, beazonosítható, hogy személyes vagy szakmai indíttatás vezérli. Formálisnak tekintjük az iskolarendszerúen szervezett képzésekben folytatott tanulmányokat, amelyek befejezése bizonyítvány, oklevél kiadásával zárul. Nonformális a hierarchizált szerkezeti struktúrán kívüli tanulás, általában nem zárul hivatalos bizonyítvánnyal; lehet olyan szervezett keretekben lebonyolított oktatási tevékenység, amelynek célja egy meghatározott csoport képzési igényeinek kielégítése. Idetartozónak tekinthetjük a munkaeró-piaci tréningeket, szakmai továbbképzéseket, tanfolyamokat, amelynek keretében elsősorban tényszerú, lexikális ismeret szerezhető. Az informális tanulás a tanulás eredeti formája, szervezett kereteken kívüli folyamat, tapasztalati úton szerzett tudás az eredménye. Ennek tekinthető a tudatos önképzés, a spontán tanulás, a szocializáció, de tanulunk így 
a médiából, internetról, a munkavégzéshez kapcsolódóan mások megfigyeléséból modellezéssel. Ez a tanulás egész életen át tartó folyamat, mert az egyének a napi tapasztalatokból, a környezeti hatásokból értékeket, attitűdöket, tudást, és nem utolsósorban kompetenciát szereznek, olyan ismereteket sajátítanak el, amelyek a munkavégzés szempontjából is relevánsak lehetnek. Visszautalva a korábbi tudásdefiníciókra, azt mondhatjuk, így alakul ki a Polányi által megnevezett (hallgatólagos) tacit tudás. A felnőttkori tanulásról folyó szakmai vita egyik szála azt tárta fel, hogy az iskolai keretek közötti tanítás-tanulás már nem képes választ adni a posztmodern kor kihívásaira, nem képes egyedüli forrásként megjelenni. A társadalmi struktúra korábbi viszonylagos állandóságának idején a lassan változó világhoz való alkalmazkodáshoz szükséges ismeretek megszerezhetôek voltak intézményi keretek között. Az általános múveltséget, a szakképzettség legfontosabb és hosszú távon fennmaradó ismereteit biztosította az iskola, ezzel akadályokat is gördített a jelentős társadalmi változások elé. Ez a szemlélet a XXI. századra tarthatatlanná vált. A tömegtermelésre berendezkedő „fordista” szervezetet felváltotta az a rugalmas vállalat, amely gyorsan alkalmazkodik a vevő igényeihez, rövid idő alatt képes akár egyedi kívánságokat is kielégíteni. Visszaszorultak a hagyományos technológiák, helyükbe lépett az a high-tech világ, amelyben a fejlődés mozgatórugója az IT-szektor. A folyamatosan megjelenó újítások a munkavállalóktól rugalmasságot, ezért permanens tanulást követelnek meg. A munkaerópiacon olyan tudások és készségek erôsödtek fel, amelyek biztosítását az iskolarendszerú oktatás nem képes megadni. A kompetenciákat az intézményrendszer nem fejleszti kellő módon, ezért felerősödött a hierarchizált rendszeren kívüli tanulási formák szerepe. Ez a változás azt eredményezte, hogy a felnőttkori tanulási kutatások meghatározójává vált a munkahelyi tanulás vizsgálata, hiszen a felnôtt társadalom tanulási tevékenységének egyre jelentősebb része realizálódik a munkahelyhez kötődően.

\section{Középpontban a munkahelyi tanulás}

A tudományos közélet téma iránti érdeklődést jelzi, hogy a 90-es évektól feltűntek azok a folyóiratok, amelyek elsősorban a munkahelyi tanulásról jelentetnek meg cikkeket. Az egyik legismertebb ezek közül az „Employee Counselling Today”, illetve jogutódja, a „Journal of Workplace Learning”, amely 1997-tól on-line formában tesz közzé tanulmányokat. Magyar nyelven nem található speciálisan ezt a témát középpontba helyezó lap, a HR-területre szakosodott folyóiratok (Humánpolitikai
Szemle, Munkaügyi Szemle), valamint a Felnőttképzés és az Educatio jelentet meg írásokat a munkahelyi tanulásról. Az említett nemzetközi folyóiratokon kívül természetesen sok jelentôs lap foglalkozik a munkahelyi tanulással annak ellenére, hogy a fogalom egyértelmú definiálása még nem történt meg. A munkahelyi tanulás fogalma szoros összefüggésbe hozható az egész életen át tartó tanulás XX. században megjelent koncepciójával. A koncepció legtöbb értelmezóje csak egy szereplőt, a munkavállalót tekinti érintettnek, holott a folyamatnak szerves résztvevớje a munkaerópiac másik oldala, a munkaadó. A munkaadók egy adott területre kiképzett dolgozóval kerülnek kapcsolatba, akinek a képessége, a kompetenciája az adott pillanatban megfeleló az elvégzendó feladat szempontjából, s akinek szakmai ismereteiról részben egy bizonyítvány, részben a munkatapasztalat során megszerzett tudás tanúskodik. Az iskolában megszerzett tudás azonban hamar elévül, a munkaadó és a munkavállaló nagyon hamar a fejlesztés-képzés kényszerú állapotába kerül. A felnőttképzésnek az a viszonylag új irányzata, amelyet ma munkahelyi tanulásként értelmezünk, megvalósulhat munkahelyen vagy munkahely által biztosított szervezeti keretek között, jelenti a szakmai képzés, továbbképzés és tanulás területeit, eredménye a személyes és társadalmi kompetencia fejlődése. A változó gazdasági-társadalmi környezethez történô legfontosabb alkalmazkodási stratégia mindkét szereplő számára a tanulás. A téma fontosságát jelzi, hogy a Központi Statisztikai Hivatal 2012-ben (Statisztikai Tükör, 2012) tett közzé egy, a munkahelyi képzésekre vonatkozó kiterjedt kutatást, amelyben a képzést támogató vállalkozások adatait korábbi kutatások eredményeivel hasonlította össze. A reprezentatív adatgyújtés több mint harmincezer vállalat képzési politikáját tárta fel 1999 és 2005 között, ötéves periódusokban. Az adatok tanúsága szerint 2010-ben a vállalkozások 49\%-a biztosított képzési lehetőséget a dolgozóinak, ez az arány megegyezik az öt évvel korábbi adattal. A vállalkozások mérete (az előző vizsgált évek adataihoz hasonlóan) jelentôsen befolyásolta a képzési hajlandóságot. A nagyvállalatok 95\%-a, a középvállalatok 74\%-a támogatott valamilyen képzést 2010-ben, ez az arány a 10-49 fốt foglalkozató vállalkozások körében $43 \%$. A képzés típusa szerinti elemzés lényegében a nonformális oktatásra fókuszál, s azt mutatja, hogy a vállalkozások a hagyományos szakmai képzést (kötött, előre meghatározott tartalommal, kifejezetten erre a célra kijelölt oktatóteremben) és a szakmai képzés egyéb formáit (a közvetlen munkahelyi szituációban folyó képzést, a tanulmányi látogatásokat, a tanulócsoportos képzést, az önképzést és a konferenciákon való részvételt) is támogatják (1.ábra). 
Képzést támogató vállalkozások aránya a képzés típusa szerint az összes vállalkozás százalékában (\%)

• Hagyományos szakmai képzések $\quad$ Szakmai képzés egyéb formái

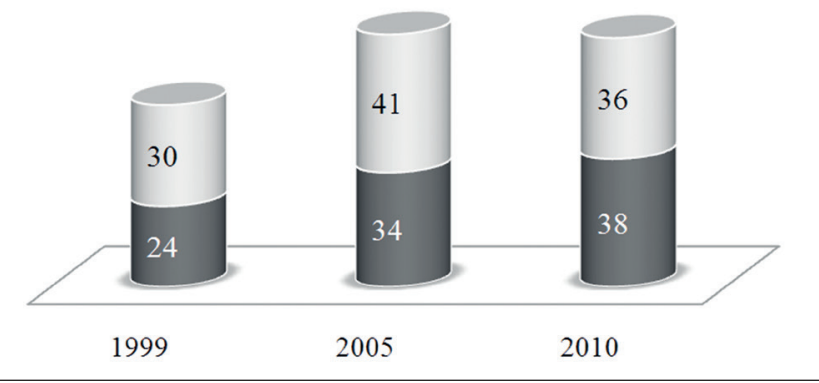

Forrás: saját szerkesztés Statisztikai Tükör 2012/16. 2. ábra alapján

2005 és 2010 között alig változott azoknak a szervezeteknek az aránya, amelyek a képzések valamilyen formáját ne támogatták volna. Eltérés csupán a belsố megoszlásban fedezhetố fel, hiszen növekedett a hagyományos szakmai képzések aránya (a KSH adatai szerint 2010-ben ezt a formát biztosító szervezetek belsố forrásokra támaszkodva szervezték meg a szakmai oktatást). Az adatok értelmezéséhez szorosan hozzátartozik, hogy az adatfelvétel idején még nem volt érvényben az új szakképzési hozzájárulásról szóló 2011. évi CLV. törvény. Az új szabályozás szerint 2012. január 1-jétől a szakképzési hozzájárulásból nem finanszírozható a dolgozók fejlesztése, a nyelvórák, tréningek költsége (ennek a változtatásnak a hatásait a képzések szervezésére csak késóbbi kutatások tárhatják fel).

\section{Tanulás, motiváció, haszon}

Tévedés lenne úgy gondolni a munkahelyi tanulásra, mintha az ténylegesen csak a legújabb korban játszott volna szerepet az egyének életében. Az emberek mindig is tanultak a munkahelyeken. 1770-ig (Mária Terézia ekkor alapította meg hazánkban az első rajziskolát az iparosok oktatása érdekében) iskolai szakoktatás hiányában a szakmai ismeretek elsajátítása a munkavégzés közben valósult meg. Az iskolák létrejötte azt eredményezte, hogy a tanulás elvált a munkától, megelőzte a termelést, egyénileg is hasznosítható életcéllá vált. A XIX. század gépesített munkahelye a szakmai tudás megszerzése után annak biztos alkalmazását, esetleg a gyorsuló munkatempót kívánta meg, a további tanulás nem volt feltétlen része a munkavégzésnek. A XX. században kialakuló fogyasztói társadalom az iparral szemben új elvárásokat támasztott. A piaci verseny eredményeként a vállalati terméknek más cégek hasonló árujától külön- böznie kell, s a megkülönböztetés egy olyan újítás eredményeként jön létre, amelyet egy részben képzettebb, de részben kreatívabb, széles körú kompetenciával rendelkezố munkavállaló képes megalkotni. Ez a kreativitás nem szerezhetố meg egyedül az oktatás hierarchizált világában. A korszerú munkahely korszerú munkavállalója mindenból és mindenhonnan kell, hogy tanuljon, életének szerves részévé válik az informális tanulás. Ennek a megközelítésnek a kutatása, az informális tanulás szerepe felerósödésének elemzése nem kiemelt témája a nemzetközi és hazai vizsgálatoknak. Az informális tanulás témakörét elsóként érintette a Központi Statisztikai Hivatal 2004-ben közzétett ,Az élethosszig tartó tanulás” kutatása, amely azt mutatta be, hogy a 15-74 éves népesség különbözố rétegei milyen mértékben kapcsolódtak be a különböző képzésekbe. A kutatás kitért az informális tanulásban való részvételre: a válaszolók harmada nyilatkozott arról, hogy tanult ebben a formában. Az informális tanulást mint önképzést és munkavégzés közben szerzett ismeretet érintette a „Kompetenciák a nonformális és informális tanulás tükrében" (Kálmán, 2009) elemzés. A 2.347 fővel végzett kérdőíves vizsgálat és a 27 fós fókuszcsoportos interjú a pedagógusszakma képviselôii, a legalább középfokú munkanélküliek és a pályakezdő munkavállalók válaszain alapul (2. ábra).

Az informális tanulás területét a „munka közben szerzett ismeret” és az „egyénileg szerzett ismeret, önképzés" elemeire vonatkozó kérdések érintik. A megkérdezettek az ismeretszerzésnek ezt a két formáját vélik a leghatékonyabbnak, nagyon magas a munka közbeni ismeretszerzés hatékonyságának minôsítése. Az informális tanulás irányultságára vonatkozóan leginkább a számítógépes ismereteket, a problémamegoldást, a kommunikációs készségeket, a munkavállalói jogokat jelölték meg a válaszolók.

$\mathrm{Az}$ informális tanulással összefüggésbe hozható adatfelvétel történt a TÁMOP 4.1.3 projekt keretében (Felsőoktatási szolgáltatások rendszerszintú fejlesztése, validációs rendszer alprojekt), de a kutatás elsősorban az ilyen úton megszerzett tudás elismerésével, és nem a formában való részvétellel kapcsolatban került sor, így nem tárt fel a munkahelyi tanulással kapcsolatos összefüggéseket. A projekthez kötődően a Debreceni Egyetem egyik képzésében kísérleti jelleggel bevezetésre került az elózetes tudás elismerése (validáció), s ehhez kapcsolódóan végeztünk két kutatást az eljárásban részt vevő hallgatók körében. A most ismertetett kutatás célja, hogy feltárja azoknak a hallgatóknak a képzési folyamatokban és az informális tanulásban való részvételét, motivációit, akik a portfolio módszerével felmérették az előzetes tudásukat. A kutatás kérdőíves megkérde- 
2. ábra Az adatok alátámasztják

Tanulási formák választásának aránya

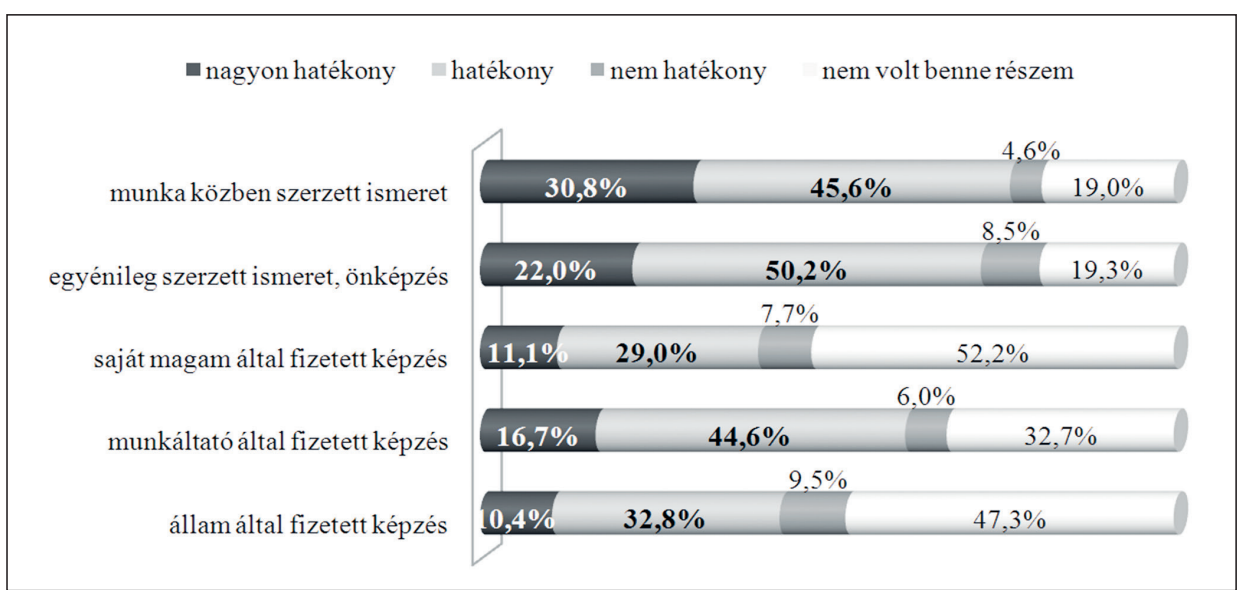

azt a feltételezést, hogy a XXI. század munkahelyén az informális tanulásban fontos szerepet játszik a munkavállalói státus. A megkérdezettek $58 \%$-a szerint ez a tanulási forma kapcsolatban van a munkatevékenységgel, $\mathrm{s}$ a tanulási motivációban közel azonos szerepet játszik az egyéni szakmai érdeklődés és a munkáltatói elvárás. A válaszolók ezt az elvárást a munkáltatóktól kapott szakmai anyagok olvasásával

Forrás: saját szerkesztés Kálmán (2009) alapján

zésen alapult, a minta tagjai a Debreceni Egyetem Emberi Erôforrás Tanácsadó MA szakos levelezố tagozatos hallgatói közül azok, akik kérvényt nyújtottak be az eljárásban való részvételre. Az EET MA szak célja olyan szakemberek képzése, akik támogatják a munkaerő-gazdálkodást, a vezetók döntési folyamatát, segítik az egyéneket pályatervezési döntéseik elôkészítésében. A képzés 4 féléves, a teljesítendő kreditek száma 120, a teljes óraszám 1.350. A végzés feltétele gyakorlati ismeretek megszerzése munkahelyi környezetben 3 félév alatt összesen 230 órában. Az elemzés tárgyát megalapozó eljárás valamennyi érintettje kitöltötte a kérdőívet. A hallgatók fele (96 fó) a tanulási formák közül az informális tanulást is megjelölte. Az informális tanulással összefüggő korábbi kutatások a részvétel tényét, és annak jellegét vizsgálták, nem tárták fel annak motivációit. Ezt figyelembe véve kerestük az összefüggést a munkavállalói státus és az informális tanulás között. A 3. ábra azt mutatja be, milyen motivációs tényezók játszottak szerepet az ismeretszerzésnek ebben a formájában. (A feldolgozásban azoknak a hallgatóknak az adatai szerepelnek, akik nyilatkoztak az informális tanulásról.)

3. ábra

Az informális tanulás indoka (\%)

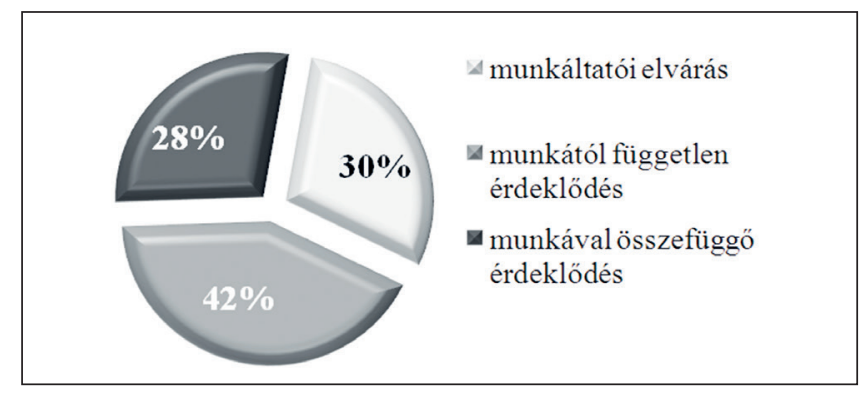

Forrás: saját szerkesztés (n=96) teljesítik (15\%), szakkönyveket, szakmai folyóiratokat olvasnak (22\%). A válaszolók 42\%-a nyilatkozott úgy, hogy az informális ismeretszerzés nincs összefüggésben a munkájával. A kutatás második részének eredményeit a késóbbiekben ismertetjük.

A felnőtt korú munkavállalók képzésére és tanulási formáira vonatkozó adatok tükrében állíthatjuk, hogy a munkahelyi tanulás mint nonformális tanulási forma meghatározó szerepet tölt be a szervezetek életében, többségük a szakmai képzés valamilyen formáját támogatja. A munkahelyi tanulás mindkét szereplôje (munkaadó és munkavállaló) számára komoly beruházás a tanulás, képzés. Az egyén fekteti be az energiát a folyamatba, feláldozza szabadidejét, sok esetben részt vállal a költségekbóll. A munkaadó számára szakmai, szervezési és anyagi kérdések merülnek fel: a munkafolyamatokat figyelembe véve kell biztosítani a szervezett formában zajló képzéseket, akkor is szükséges beruháznia az oktatásba, ha annak fedezete csak nehezen teremthetô elő. Ezek a vállalások mindkét fél részéról felvetik a kérdést: megtérül-e a befektetés, lesz-e haszna a tanulásnak/képzésnek? A formális tanulás haszna az egyén és a társadalom számára is kézzelfogható eredménnyel jár, ahogyan azt egy hazai kutatás bemutatta (Polónyi, 2004). A végzettségek szintje szerinti vizsgálati eredmények a többlettudás hasznát bizonyították. A nonformális és informális tanulás hasznosulásáról alig készül felmérés. Felfogásunk szerint a tanulás haszna az egyén-, szervezet- és az oktatási rendszerben történó érvényesítés szempontjai szerint is csoportosítható. Az oktatási rendszerben történő érvényesítés vizsgálatát az Európai Unió tudáselismerési eljárása okán tartjuk fontosnak (1. táblázat).

A formális tanulás haszna bizonyított tény az egyén, a szervezet és az oktatási intézmények szempontjából egyaránt. A nonformális és informális tanulás haszna 
A különböző tanulási utakon szerzett tudás haszna

\begin{tabular}{|l|l|l|l|}
\hline & \multicolumn{1}{|c|}{ Személyi haszon } & \multicolumn{1}{c|}{ Szervezeti haszon } & $\begin{array}{c}\text { Haszon az oktatási } \\
\text { intézményben }\end{array}$ \\
\hline $\begin{array}{l}\text { Formális } \\
\text { tanulás }\end{array}$ & $\begin{array}{l}\text { - szakmai felkészültség bizonyítása } \\
- \text { munkahelyi pozíció javulása }\end{array}$ & $\begin{array}{l}\text { - szakmailag alkalmas munkaeró megtalálása } \\
- \text { munkavégzés közben }\end{array}$ & - egymásra épülő képzésekben \\
\hline $\begin{array}{l}\text { Nonformális } \\
\text { tanulás }\end{array}$ & $\begin{array}{l}- \text { ismeretek bóvülése } \\
- \text { kompetenciák fejlődése } \\
- \text { munkahelyi pozíció javulása }\end{array}$ & - munkavégzés közben & $-\begin{array}{l}\text { nincs kialakult gyakorlat } \\
\text { (általában nyelvi } \\
\text { képzésekben beszámítják) }\end{array}$ \\
\hline $\begin{array}{l}\text { Informális } \\
\text { tanulás }\end{array}$ & $\begin{array}{l}- \text { kompetenciák fejlódése } \\
- \text { esetenként szakmai tudás fejlődése } \\
- \text { gyakran nem tudatosul }\end{array}$ & - munkavégzés közben & $\begin{array}{l}\text { nincs kialakult gyakorlat } \\
\text { (általában nyelvi } \\
\text { képzésekben beszámítják) }\end{array}$ \\
\hline
\end{tabular}

Forrás: saját szerkesztés

azonban korántsem egyértelmú. Álláspontunk szerint az egyének a nonformális tanulás eredményét az intézményi keretekben megszerezhető tudás eredményével akarják összehasonlítani. Az összevetés alapjának tekintik a tanulás szervezettségét, a kötöttségek, az erőfeszítések szükségletét, valamint az írásos dokumentum (valamilyen tanúsítvány, igazolás) kiadását. Ezeknek a képzési lehetőségeknek a szervezése vagy biztosítása több esetben is a munkahelyhez kötődik, a szervezeti szükségletek és igények alapján folyik, ezért annak hasznát - a munkavégzés közben a kompetenciák és ismeretek bővüléseként - rövid visszacsatolás útján felméri a munkaerôpiac mindkét szereplője. A munkahely szempontjai szerint részben a gyakorlatban azonnal alkalmazható, részben a papír által igazolt tudás a fontos. Az előzetes tudás felmérése kifejezést a szervezetek nem használják, ennek ellenére létezik az elismerés gyakorlata. A felvételi interjúk jellemzô pontja az ismeretanyag feltérképezése, szívesen veszik a különbözô módokon megszerzett tudás és a kompetenciák bemutatását a motivációs levélben. A kommunikációs készségek megléte, a csoportmunkára való alkalmasság, a projektgondolkodás, a nyelvtudás (és nem a bizonyítvány) olyan kompetenciák és ismeretek, amelyek lassan már a középvezetốk esetében is természetesek. Az informális tanulás útján megszerzett tudás elismertetése összetettebb. Az a tudás, amit az egyének az életük során önálló tanulással vagy tapasztalati úton szereztek, sok esetben még önmaguk számára is nehezen beazonosítható, hiszen bizonyítani csak munkavégzés közben tudják. Az informális tanulás eredményét a munkahelyeken a nonformális úton szerzett tudáshoz hasonló módon elfogadják, értékelik. $\mathrm{Az}$ oktatási rendszerben a nonformális és informális úton szerzett tudás érvényesítése korántsem egyszerú. $\mathrm{Az}$ ismereteket igazoló tanúsítvány nem kompatibilis a hivatalos bizonyítványokkal, a kompetenciák beazono- sítására nincs kialakult gyakorlat. A felnőttképzési intézményeket törvény kötelezi az előzetes tudás felmérésére, az ismétlések kiküszöbölésére, de sok esetben ezt csak a nyelvi kurzusok csoportjainak kialakításakor alkalmazzák. A felsőoktatási intézményekben még erre sincs kialakult gyakorlat. Az iskolák, az egyetemek nem tudnak vagy nem akarnak kezdeni semmit az informális úton megszerzett tudással. A megközelítés hátterében részben az áll, hogy az oktatás a státusversengés egyik eszköze, az egyének társadalmi státusa függ a végzettségtôl, $\mathrm{s}$ az elismerés magában hordozza annak a kockázatát, hogy egyesek kevesebb erófeszítéssel szereznek meg szimbolikus javakat, s ezzel társadalmi és gazdasági elónyökhöz jutnak. Az előzetes tudás elismerése különösen a társadalmi kiváltságokkal rendelkezố rendszerekben (ilyen az egyetem) válthat ki nagy ellenállást (Michelson, 2006), mert itt folyik a legnagyobb harc az erőforrások megszerzéséért.

Tanulmányunkban már részleteztük, hogy a munkaerốpiac mindkét szereplője számára jelentős beruházás a tanulás, bármilyen formában történjen is az. Az egyéntól energiát, idôt, részben anyagi ráfordítást, a munkaadóktól szervezést, beruházást kíván. Az eróforrásokkal, a tudással való gazdálkodás szempontjait figyelembe véve fontos, hogy a felnóttek tanulási folyamatában kiküszöbölhető legyen az ismétlődés, felismerhetôvé váljon a tudás hasznossága, a tanulás folyamatáról való gondolkodásban szemléletváltozás történjen, az elismerést az oktatási intézmények is bevezessék. Ez a szemléletváltás az Európai Unió több államában is megtörtént, hazánkban most zajlanak az elsố kísérletek.

\section{Az elôzetes tudás elismerésének rövid áttekintése}

Az előzetes tudás elismerésének leghosszabb időre viszszatekintố hagyománya Franciaországban van (már az 1930-as években a mérnöki szakmában lehetôség volt arra, hogy a gyakorlati tevékenység során szerzett tudást 
egy állami mérnöki diploma kiadásával ismerjék el). Itt a validáció kifejezést használják, s mára az európai szóhasználatban is ez terjedt el leginkább. Az elismerés az egyetemi programokban az Egyesült Államokban és az Egyesült Királyságban jelent meg elôször az 1990es években, amelynek keretében a tapasztalati tanulás mennyiségi mérésén kívül annak az oktatási rendszerbe való beépítése, a felvételi és tanulmányi mentességek kialakítása is megtörtént. A kísérleteket folyamatos tudományos kutatások mellett végezték, amelyeknek eredményeként a rendszer ismertté vált az egész világon. A módszert először alkalmazó országokban a cél a foglalkoztatási és képzési lehetóségek fejlesztése volt, amely egyúttal új utakat nyitott a felsőoktatásban is. Az európai elterjedést és az elméletek újratárgyalását az Európai Bizottság 2006-os felnőttkori tanulásra vonatkozó cselekvési programja gyorsította fel, amely hangsúlyozta, majd 2011-ben megerősítette ennek az integrált rendszernek a kifejlesztését (I1). A program alapgondolatát olyan statisztikai mutatókra alapozták, amelyek szerint a felnőttkori tanulásban való részvétel csökkent a 25 és 64 év közötti népesség körében. 2005-ben ebben a korcsoportban 9,85\% volt az arány, amely 2010-re 9,1\%-ra csökkent (I1: C372/2). A cselekvési terv 2020-ra 15\%os tanulási részvételt tart kívánatosnak, ezért látta szükségesnek a program kidolgozását. Az elvárások között a felsôoktatási intézmények számára is szerepel felszólítás. Az egyes tagállamoknak olyan rendszert kell kialakítania, amelyek ösztönzik az egyetemeket arra, hogy vegyenek fel kevésbé hagyományos profilú hallgatókat (pl. felnőtteket), s ezzel megfeleljenek a társadalmi igényeknek, a demográfiai kihívásoknak. Az állásfoglalás szerint az elôzetes tudás elismerése az egész életen át tartó tanulásra irányuló stratégia sarkalatos pontja. A bármilyen formában megszerzett tudás elismerése lehetôvé teszi az érintettek számára, hogy egy adott szinten bekapcsolódhassanak egy tanulási programba, kompetenciákra alapozva előrelépést tegyenek egy képesítés megszerzése felé. Az elismerés értéket ad a korábbi tanulásnak, az egyén idôt és pénzt takarít meg azáltal, hogy csökkenti vagy megszünteti az újratanulást. A társadalom is profitálhat az elismerési eljárásrendból, mert kevesebb közpénz felhasználásával juttatja tudáshoz az embereket. A javasolt program az Európai Bizottság szerint elősegíti, hogy a munkáltatókban még jobban tudatosuljon, hogy a tanulás hozzájárul a versenyképesség, az innováció és a vállalkozói készség és a munkavállalók munkaerô-piaci mobilitásának növeléséhez. Az előzetes tudás elismerésének megközelítését Franciaországban is változások kísérték. A törvényi hátteret többször módosították, a legutolsó változás 2002-ben lépett életbe, amelynek értelmében képesítés akár egyetlen intézmé- nyi modul teljesítése nélkül is megszerezhető legyen. A törvény megalkotóit társadalompolitikai tényezók befolyásolták. Franciaországban azt ismerték fel, hogy a munka melletti tanulási formák jelentôs része nem ad végzettséget. A felmérések azt bizonyították, hogy a munkavállalók 30\%-a olyan munkakört tölt be, amelyhez megvan a szakmai tudása, de nincs meg a végzettsége. Olyan elismerési eljárásokat vezettek be, amelynek eredményeként a valamilyen formában megszerzett tudás elismerése által a tanulmányi mentesség elérhetô. Természetesen a politikusokra költségvetési szempontok is hatottak. Komolyan megnövekedett a végzettséggel rendelkezók száma úgy, hogy annak költségvetési kiadásai meg sem közelítették a képzés teljes idejére fordítandó összeget. A felsőoktatás világában alkalmazott eljárásrend elfogadásáról, tapasztalatairól kevés elemzés készült. Ezek egyike Marin Gross tanulmánya (Gross, 2008) amely az Egyesült Királyság, Svédország, Belgium és Észtország validációs tapasztalatait tárta fel, ahol már komoly múltja van a tudás elismerésének. Az eredmények szerint az egyik legnehezebb feladat a validáció során, hogy az előzetes tanulás nem kötődik a tantervek logikájához, ezért roppant nehéz beleilleszteni abba. Bár minden tanulás alapja a tapasztalat, az egyetem tudományos világa mégis nehezen fogadja el azt. Több országban is az volt az oktatók véleménye, hogy az egyetem nem az a hely, ahová hozzák a tudást, hanem az, ahonnan viszik. A másik nehézséget az elismerési eljárás szemléletének elfogadása jelenti, mert a validáció egy tanulóközpontú folyamat, a hangsúly a vizsgáztató tanárról a tanulóra esik. A validáció nagyfokú hozzáférést biztosít a tanulóknak olyan javak megszerzésére, amelyhez az eljárás nélkül nem juthatnának hozzá, s ez több helyen is ellenérzéseket vált ki. Az egyetem és az egyén érdekei nagymértékben különböznek egymástól. Az egyén érdeke a tudást igazoló dokumentum rövidebb úton való megszerzése, az egyetem érdeke a tudást igazoló bizonyítvány nehezebb feltételek mellett történő megszerezhetôsége. Marin Gross kutatásának egyik fontos megállapítása, hogy mára már a professzorok is elismerik, hogy a validációs eljárással bekerült hallgatók sokkal motiváltabbak társaiknál.

Magyarországon az előzetes tudás értékelése kifejezést a 2001-es felnőttképzési törvény fogalmazta meg. A 17. § (2) szerint: „A képzésre jelentkező felnőtt kérheti tudásszintjének előzetes felmérését, amelyet a felnőttképzést folytató intézmény köteles értékelni és figyelembe venni." 2004. VI. 22. FMM az akkreditációs eljárás szabályairól szóló rendelet 8.§-a elő́rija, hogy az előzetes tudásszint mérésének kötelezettségét a felnőttképzési tevékenységet folytatók esetében. A felsőoktatásban a munkatapasztalatból származó tudás elismeré- 
sét a 2005. évi CXXXIX. törvény 58. § (7) bekezdése szabályozta, amely szerint a korábbi tanulmányokat és a munkatapasztalatot legfeljebb harminc kredit erejéig tanulmányi kötelezettség teljesítéseként el lehet ismerni. Az új, 2011. évi CCIV. törvény a nemzeti felsőoktatásról az elismerést a 49. § (6) és (7) pontjaiban rögzíti, és a következő módon szabályozza: „(6) A kreditátviteli bizottság az elózetesen megszerzett tudást, munkatapasztalatot e törvényben, valamint kormányrendeletben meghatározottak szerint - tanulmányi követelmény teljesítéseként elismerheti. A 49. § (3)-(6) bekezdésben meghatározottak végrehajtásával kapcsolatos kérdéseket a tanulmányi és vizsgaszabályzatban kell szabályozni, azzal a megkötéssel, hogy a hallgató a végbizonyítvány (abszolutórium) megszerzéséhez - a felsőoktatási intézményben folytatott, illetve más korábbi tanulmányok, továbbá az elôzetesen megszerzett tudás kreditértékként való elismerése esetén is - a tanulmányi és vizsgaszabályzat szerinti kreditet, de legalább a képzés kreditértékének harmadát az adott intézményben köteles teljesíteni." A törvényhez kormányrendelet a vonatkozott szakasz esetében még nem készült, a munkatapasztalat fogalmának meghatározása nem történt meg. A beszámítható kreditek tekintetében nagy mozgásteret enged a törvény, az előzetesen megszerzett tudással a képzés kreditértékének akár $2 / 3$ része is kiváltható. Ez a lehetôség az Európai Unió államaiban alkalmazott validációs gyakorlat egy részénél is nagyobb szabadságot biztosít a magyar egyetemeknek. A törvényhozást megelózte, hogy a kormány az előzetes tudás elismerésének ügyét a TÁMOP 4.1.3. projekt egyik elemeként támogatta, ennek eredménye a validációról szóló átfogó munka (Derényi - Tót, 2011), amely egy általánosan érvényesíthetô eljárásrend alapjait írja le.

A projekt előzményének tekinthetô az a kutatás, amely a Tempus Közalapítvány megrendelésére készült (Derényi, 2008), és egyebek mellett a formális tanuláson kívüli szerzett tudás elismerésével összefüggó gyakorlatra és attitúdre fókuszált. Az elemzésben 26 felsőoktatási intézmény 134 oktató és nem oktató státusban álló alkalmazottja töltötte ki a kérdőívet. Az összes válaszoló 12,3\%-a úgy vélte, nem kívánatos a formális kereteken kívül szerzett tudás elismerése a felsőoktatásban, és 23,5\% szerint erre nincs is igény. A 2005. évi felsőoktatási törvény hatályának idején a TÁMOP 4.1.3. projekt keretében készült egyik kutatás (Kraiciné, 2010) részletesen elemzi a munkatapasztalat beszámítására vonatkozó eljárásrendeket és a validációval kapcsolatos attitúdöket. A nem formális környezetben megszerzett tudás - a munkatapasztalat - beszámítása kapcsán a kutató eredménye szerint a részidős képzési formákban a 3 éves munkatapasztalatot több intézményben is elfo- gadják az intézményen kívüli gyakorlat teljesítéseként. A kutatás példaként említi a Corvinus Egyetemet, ahol a levelező tagozatos képzések esetén tételesen felsorolja azokat a közszférába tartozó munkahelytípusokat, ahonnan érkezó hallgatók egyéni kérelmét a munkáltatói igazolás megléte esetén az oktatási dékánhelyettes bírálja el. A kutatásban megkérdezett oktatók mintegy 8\%-a nyilatkozott úgy, hogy a továbbképzésekben megszerzett tudás beszámítását elképzelhetônek tartaná, de még az 5\%-ot sem érte el azon válaszolók száma, akik az informális úton megszerzett tudást elismerhetőnek vélik. A vizsgálatban nem találtak arra vonatkozó gyakorlatot vagy példát, hogy a munkahelyi tanulás vagy az önképzés bármely formáját a felsőoktatásban elismernék, sôt erre vonatkozó tervek sem léteznek.

Hasonlóképpen a civil szférában szerzett kompetencia elismerése sem vetődik fel, még az egyházi intézményekben sem, ahol pedig gyakran előfordul, hogy a hallgatók rendelkeznek egyházi közösségekben megszerzett validálható tudással. A validációval kapcsolatos attitúdvizsgálat eredménye szerint az oktatók ellenérdekeltek a folyamatban. A validáció pluszfeladatként jelenik meg, nem számítható be az óraterhelésbe, a tanulmányi osztály munkatársai számára pedig olyan külön feladat, amelyért nem jár díjazás. A kutatók arra is keresték a választ, van-e a munkaadók oldaláról bármilyen vélemény a validációval kapcsolatban. A Kereskedelmi és Iparkamarához az egyetemek részéról semmilyen megkeresés, információkérés nem érkezett, nincs élố kapcsolat a kamara és az intézmények között. Ennek ellenére a kamara nyitottságot mutatott a munkatapasztalat által megszerzett tudás elismerésével kapcsolatban. Munkavállalók körében 2004-ben készült először kutatás (Varró, 2004) levelezó tagozatos hallgatók körében az informális tanulás eredményének hasznosításáról. A vizsgálatban részt vevő hallgatók még csak két évet tanultak a kreditrendszerben, ennek ellenére a megkérdezettek 87,3\%-a elfogadhatónak tartaná, ha a korábban megszerzett tudását kreditekben elismernék.

A TÁMOP 4.1.3. projektben kidolgozott elképzelések intézményi szintû́ kipróbálásában a Dunaújvárosi Főiskola volt a közremúködô. Tanulmányunkban korábban már utaltunk arra, hogy a projekt elemeinek megismerése kapcsán a Debreceni Egyetem Gyermeknevelési és Felnőttképzési Kara tett kísérletet önállóan a validáció megvalósítására az Emberi Erôforrás Tanácsadó MA képzés levelező tagozatán 2011-ben. A most ismertetésre kerülő kutatásban a validáció bevezetése elôtt felmértük a szakra beiratkozott hallgatók különböző tanulási módokban való részvételét. A megkérdezés idején 317 hallgató került jogviszonyba ezen a szakon levelezó tagozaton a karral, a kitöltési hajlandóság 100\% volt. 
A munkatapasztalat megszerzésének formái

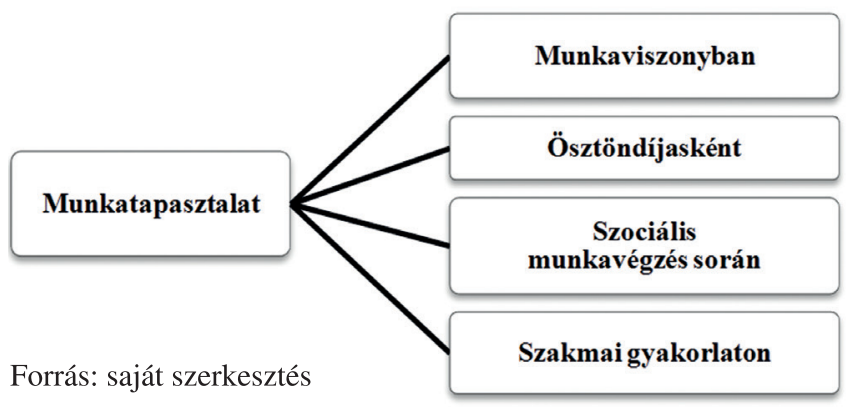

A mesterképzésben részt vevő hallgatók $85 \%$-a nyilatkozott úgy, hogy az alapdiploma megszerzését követôen is fejlesztette tudását valamilyen módon. Iskolai kereteken kívül a hallgatók 30\%-a egyszer, 32\%-a kétszer, $13 \%$-a háromszor, $10 \%$-a háromnál több alkalommal vett részt képzésben. A hallgatók 41\%-a esetében a munkáltató fizette a képzés teljes költségét, s további $18 \%$ esetén is részt vállalt a költségekben. A megkérdezettek döntő többsége (80\%) hasznosnak és eredményesnek ítélte meg azt a képzést, amelyben részt vett, az anyagi és személyes tehervállalás megtérült a számára. A válaszolók egyharmada olyan képzésben szerzett új ismereteket, amelyet a munkahelye szervezett. Az iskolai rendszeren kívüli képzésben való részvétel motivációjaként a válaszolók 32\%-a a kompetenciák növelését, 20\%-a munkáltatói elvárást, $16 \%$-a új munkahely esélyét, $5 \%$-a a munkahely megtartását jelölte meg. A hallgatók fele nyilatkozott úgy, hogy rendszeresen képzi magát informális úton. A megkérdezés eredménye megfelelő alapot teremtett az elózetes tudás elismerési eljárásának (validáció) kísérleti bevezetésére. A nemzetközi szakirodalom alapján a validáció első lépéseként a kar definiálta a munkatapasztalat fogalmát ezen a szakon: munkatapasztalat az olyan tevékenység, amelyet a kérelmező hallgató legalább 3 évig folytatott (nem feltétlenül folyamatosan), és az alábbi munkaterületekról származik: bármely vállalat/vállalkozás humánpolitikai, vagy az ilyen feladatokat ellátó szervezeti egysége, közigazgatási, közszolgálati szervezet/intézmény humánpolitikai szervezeti egysége, munkaügyi központ bármely szervezeti egysége, munkaerő-közvetítéssel, kölcsönzéssel foglalkozó szervezet, karrier- és életviteltanácsadással foglalkozó szervezet, pályaválasztással, pályatanácsadással foglalkozó szervezet, munkaerő-piaci, foglalkoztatási folyamatokkal foglalkozó szervezet, felnőttképzéssel, felnôttoktatással foglalkozó szervezet.
A 4. ábra mutatja be, hogy az eljárásrend alapján a munkatapasztalat több formában is megvalósulhat.

A meghatározás elve a XXI. század atipikus foglalkoztatási formáinak elismerése. Az elôzetes tudást a kar a gyakorlati és a szakmai kurzusok követelményeinek teljesítéseként is elismeri. A gyakorlat kiváltására irányuló kérelem elbírálása a munkát adó szervezet által kiadott foglalkoztatást igazoló dokumentum vizsgálata, valamint egy részletes, a konkrét munkatapasztalat leírására szolgáló szakmai önéletrajz alapján történik. Az előzetes szakmai tudás megállapításakor ez a követelmény újabb elemekkel egészül ki. Két módszert ötvözött az intézmény: a deklaratív módszert (a dokumentumok alapján történő beszámítást) és a kompetenciaportfóliót (a munkavégzés során keletkezó kompetenciák bizonyítását), amelyet szóban is meg kell védeni. Az 5. ábra mutatja be a portfólió tartalmi elemeit.

5. ábra

\section{A portfólió elemei}

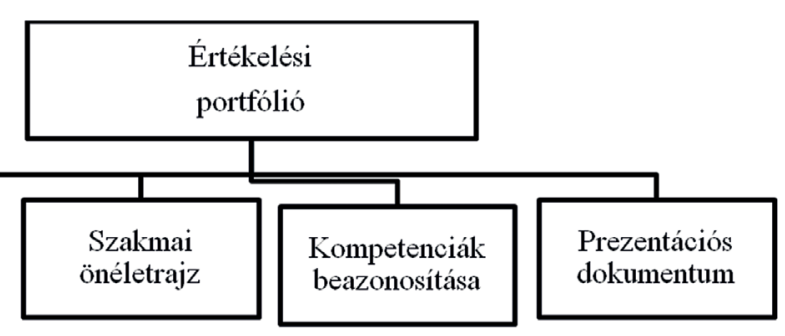

A tanulmányok felsorolása csak részben jelenti a formális keretek között megszerzett bizonyítványok bemutatását. A validációs bizottság értékel minden kurzust, tanfolyamot, amelyben a kérelmezô ismeretekre vagy új kompetenciákra tett szert. A szakmai önéletrajz tartalmi követelményei között szerepel a szakmai tevékenység részletes kifejtése, a napi munkatevékenység leírása, megnevezve, hogy az elvégzéshez szükséges ismeretekre milyen úton tett szert a hallgató. Elvár a bizottság egy munkahelyi értékelést, az elismerések felsorolását. A kompetenciák beazonosítása a legnehezebb feladat a kérelmezók számára, a tanácsadási szolgáltatásnak ebben a szakaszban van a legnagyobb jelentősége. A prezentációs dokumentum a szóbeli meghallgatás során előadásra kerülő ppt bemutató előzetesen benyújtott anyaga. Az eljárásrend lebonyolításához a Gyermeknevelési és Felnőttképzési Kar Tanácsadó és Felnőttképzési Központot hozott létre, tanácsadói szolgáltatást biztosít. Az eljárás formai és tartalmi követelményeit a validációs bizottság folytatja le, amelynek tagjai a szak oktatóiból és a szakma képviselóiból állnak. Az értékelésben a bizottság az alábbi szempontokat veszi figyelembe: a beadott dokumentumok hitelessége, a do- 
kumentumok világos magyarázata, a gondolati mélység, önértékelés, minőség, forma. A validációs eljárásban a hallgatók térítés ellenében vehetnek részt.

A validációs kísérlet komoly hallgatói érdeklődés mellett folyik a karon. A szakon jogviszonyba került 337 hallgató közül 114 fő kérte a gyakorlati követelmények, 39 fő a tantárgyi követelmények alóli felmentést. A tanácsadás egyebek mellett azt is jelentette, hogy a hallgatói anyagokat egy előzetes formai bírálatnak vetették alá, amelynek alapján 7 hallgató visszavonta a tantárgyi elismerésre vonatkozó kérelmét. A sikeres validáció a költségtérítéses képzésben részesüló hallgatók számára megadja az esélyét, hogy a kiváltott krediteknek megfelelően csökkenjen a költségtérítés összege. A portfólió értékelését igény esetén a kar (a hallgató hozzájárulása esetén) a munkáltató számára elérhetôvé teszi. Az eljárásból leszúrhetố tapasztalatokat felhasználva a Debreceni Egyetem keresi a megoldást, hogy más karokra is kiterjessze az előzetes tudás elismerésének lehetőségét. $\mathrm{Az}$ egyetem szenátusa Validációs Bizottságot hozott létre, amely koordinálja, támogatja a validációs folyamatot. Új útkeresésként a TÁMOP 6.2.2/B/12/1 projekt keretében valósul meg a képzések közötti átjárhatóság és a munkatapasztalat elfogadása az OKJ ápoló - BsC ápoló, illetve a mentőápoló-mentőtiszt képzési programokban. Az elózetes ismeretek beszámítása által lehetôvé válik a diplomás alapképzés idejének lerövidülése. A Debreceni Egyetem Gyermeknevelési és Felnőttképzési Karának kísérlete modellként szolgálhat más felsốoktatási intézmény számára is.

A törvényi lehetőség és a kísérletek eredményeinek felhasználása Magyarországon is megteremtette az előzetes tudás elismerésének bevezetését a felsőoktatási intézmények számára. A nemzetközi példák azt bizonyítják, hogy az akadémiai szféra minden országban próbált ellenállást tanúsítani, de a megfelelô szabályozás, az eljárás által felvett hallgatók motiváltsága változtatott a szemléletmódon. Több országban kutatások, Észtországban doktori program épül a validációval öszszefüggó kérdések feltárására. A nemzetközi tapasztalatok és az Európai Unió állásfoglalásai nyomán várható, hogy a validáció hazánkban is egy elfogadott eleme lesz a felsőfokú képzéseknek.

\section{A validáció szerepe a munkaerố-piacon}

Meglátásunk szerint a munkahelyi tanulás fogalma és az előzetes tudás elismerése (validáció) szorosan kötódik egymáshoz mind a munkaadó, mind a munkavállaló nézőpontjából. A nagyvállalatok erőforrásokat biztosítanak munkavállalóik képzésére, az alkalmazottak energiát fektetnek be, sok esetben részt vállalnak a költségekból, feláldozzák szabadidejüket. A hatályos felsőoktatási törvény megteremti a lehetőségét a különböző tanulási utakon szerzett tudás elismerésének, s felfogásunk szerint ez a validáció a munkaerópiac szereplói számára előnyökkel jár.

A validáció mint munkaadói érdek: A formális úton megszerzett tudás még akkor is számottevő költséggel jár, ha államilag finanszírozott képzésben vesz részt egy munkavállaló. A tanulmányi szerződéssel támogatott tanulás esetén az utazási költség, a tanulmányi szabadság idejére kiesố teljesítmény is érinti a munkáltatót. Ez a költség csökkenthetố azáltal, ha az egyén valamilyen úton már korábban megszerzett tudását beszámítanák az egyetemek, s ezzel rövidebbé válna a képzési idő. A validáció elfogadása először jelentősebb cégek esetében valósulhatna meg. A nagy- és multinacionális vállalkozások humáneróforrás-szakemberei rendelkeznek olyan homogén csoportokkal, amelyeket beiskolázhatnának a validációs eljárás keretében. A validációval elérhető rövidebb tanulmányi idő következményeként a vállalatnak nem kellene a teljes kurzust anyagilag támogatnia. Az így megszerzett tudás és végzettség egyenértékú a teljes idejú kurzusok eredményével, ugyanakkor alacsonyabb költségvetéssel és a munkavállalók rövidebb idejú távollétével jár. A kis- és középvállalkozások számára a validációt erôsítheti az Új Széchenyi Terv számukra kiírt „Munkahelyi képzések támogatása” projekt, amelynek célja az alkalmazottak munkahelyi készségeinek és kompetenciáinak javítása, ezzel a vállalkozás versenyképességének erôsítése. Az elôzetes tudás felmérésének segítségével a szervezet képet kaphat alkalmazottjai tényleges felkészültségéról, ezzel lehetővé válik egy szervezeti átalakítás, a szellemi kapacitások felmérése pedig megalapozhat egy stratégiai tervet, hatékonyabbá teheti a képzési rendszert. A már meglévô tudás feltérképezése alapján szervezett képzések növelhetik azoknak a számát, akik részesülhetnek a képzésben.

A validáció mint munkavállalói érdek: A validáció hozzájárul a társadalmi integrációhoz, a foglalkoztathatósághoz, elósegíti a további tanulást. Egy újabb tréning, tanfolyam, esetleg felsőfokú tanulmány során megszerzett tudás hasznosulása/hasznosítása azonban csak kevés esetben érvényesül, ezért a tudással rendelkezó egyén számára fontos lehet ennek a tudásnak az elismertetése. A különböző módokon megszerzett tudás szerencsés esetben az egyén számára egységes egésszé áll össze, része szakmai fejlődésének, munkahelyi elismerésének. A validációs eljárásban résztvevók növelik a saját tudásukkal kapcsolatos ismereteiket, tudatosabbá válnak képességeik fejlesztésének lehetőségeit illetôen, könnyebbé válik számukra a belépés egy formális képzési programba. Az elôzetes tudás felsôoktatásban 
történő elismerésével megszerzett diploma új lehetőségeket teremt a külsố munkaerópiacon, de megteremti a vállalaton belüli karrierlehetôségeket is. A validációval a képzésben résztvevớk csökkenthetnék tanulmányi terheiket, a tanulmányokra fordított összeget, rövidebb idő alatt szerezhetnének képesítést, hamarabb realizálhatnák annak munkaerő-piaci hasznát.

\section{Összefoglalás}

Tanulmányunk áttekintést kívánt adni az elôzetes tudás, a munkahelyi tanulás és a tudás felsőoktatási keretekben elismerése tárgykörében. Célunk az volt, hogy ráirányítsuk a szervezetek figyelmét egy olyan törvény által biztosított lehetôségre, amelynek bevezetése érdeke a munkaerô-piaci szereplő́knek is. Érintettük a tudás, a tanulási formák, a munkahelyi tanulás és a tudáselismerés tárgykörét, bemutattunk egy múködő kísérletet az előzetes tudás elismerésérôl. Megítélésünk szerint a felnőttek számára a tudás beazonosítása, átvitele, új környezetben való alkalmazhatósága kulcskérdés a munkahelyekért folyó versengésben. A tanulásnak, az érvelésnek, a tervezésnek az alapja a transzfer, amelynek eredménye könnyebbé teszi az újabb ismeretek elsajátítását. A transzferálás olyan képesség, amely a különböző tanulási szintekhez való alkalmazkodás során alakulhat ki az egyénben, szintetizáló, kommunikációs képességet feltételez, melynek segítségével a korábban megszerzett ismereteket új megvilágításban kell látnia az egyénnek. Kompetenciák előhívásáról van szó, amely csak megalapozott tudás esetén valósulhat meg. A felnőtt, tudással rendelkezô munkavállalók számára jelentôséggel bír előzetes tudásuk elismerése a munkahelyeken és a felsôoktatásban egyaránt. Az Európai Unió több tagállamában a felsóoktatási szektor szereplói már felismerték, hogy a nonformális és informális úton megszerzett tudás egyenértékú lehet a formálisan megszerzett ismeretekkel, ezért a tudás elfogadása és az elismerési rendszer egyetemeken történó bevezetése hosszabb távlatokban hazánkban is szükségessé válik. Ebben az elismerési folyamatban az elôzetes tudás kettős szerepet tölt be: egyrészt eszköz, mert a meglévő tudás egyben újabb tudás megszerzésére ad lehetőséget; másrészról cél, mert egy meglévő tudás nyereség az egyén és a szervezet számára azzal, hogy kevesebb idôt és pénzt kell a tanulásra fordítani. Hazánkban az egyetemek/főiskolák még csak ismerkednek az előzetes tudás elismerésének elveivel, de a kutatások szerint nagyon gyenge az érdekeltségük. Ez a megközelítés változhat, ha a szervezetek, a szakmai kamarák megfogalmazzák a tudáselismerés iránti igényüket, s ezzel felgyorsítják a törvény által már biztosított validáció széles körü elterjedését.

\section{Felhasznált irodalom}

Benedek I. (1994): A tudás útja. Budapest: Magyar Könyvklub Boutellier, R. et al. (2000): Managing Global Innovation. Berlin: Springer

Csapó B. (2002): A tudáskoncepció változása. Új Pedagógiai Szemle, 2. sz.: 38-45. o.

Derényi A. (2008): A bolognai folyamat magyarországi célkitúzéseinek megvalósítása. Bologna Füzetek 5. Budapest: Tempus Közalapítvány

Derényi A. - Tót É. (2011): Validáció. Budapest: Oktatáskutató és Fejlesztő Intézet

Gross, M. (2008): Assessment of prior experiential learning in higher education context. Tallin: Tallinn University

Kraiciné Szokoly M. (2010): Pillanatkép a validáció helyzetéról. Gyorsjelentés a felsőoktatás, szakképzés, felnőttképzés, a munkaadók és a civil szervezetek körében végzett terepmunkáról. OFI Tudástár. http://tamop413.ofi.hu/ tudastar/projekt-kereteben (letöltés: 2013. 06.12.)

Kálmán A. (2009): Az életen át tartó tanulást megalapozó kompetenciák kialakulása a nonformális és informális tanulás dimenziójában. in: 5. Magyar Nemzeti és Nemzetközi LifeLong Learning Konferencia. MELLearN Egyesület Debrecen: 170-187. oldal

Lengyel B. (2004): A tudásteremtés lokalitása. Tér és Társadalom, 18. évf. 2.: 51-71. oldal

Lévai Z. - Bauer J. (2004): A személyügyi tevékenység gyakorlata. Budapest: Szókratész Külgazdasági Akadémia

Michelson, E. (2002): Multicultural Approaches to Portfolio Development. Assessing Adult Learning. University of Phoenix. New York: John Wiley \& Sons

Mihály I. (2003): Felnőttek tanulása - elméleti és gyakorlati tapasztalatok. Új Pedagógiai Szemle, 10. sz.: 120-132. o.

Móré M. (2011): Te csak beszélj, és könnyen beilleszkedem. A beillesztés kommunikációs összefüggései. VIKEK Közlemények, 2011. 1-2.: 43-51. oldal

Polányi M. (1994): Személyes tudás: úton egy posztkritikai filozófiához. Atlantisz Kiadó, Budapest

Polónyi I. (2004): A felnőttképzés megtérülési mutatói. Kutatás közben. Budapest: Felsőoktatási Kutatóintézet

Sveiby, K. E. (2001): Szervezetek új gazdasága: a menedzselt tudás. Budapest: KJK - KERSZÖV Jogi és Üzleti Kiadó

Varga (2010): Mennyit ér a diploma a kétezres években Magyarországon? Educatio, 3.: 370-383. o.

Varró F. (2004): Ajövő márkajegye: a gyors változás: Egy lépés a nem formális képzés elismerése felé. Felnőttképzés, 2. évf. 4. sz.: 33-41. oldal

Statisztikai Tükör VI. évf. 16. sz. 2012. Központi Statisztikai Hivatal, Budapest

Az élethosszig tartó tanulás. Központi Statisztika Hivatal 2004, Bp.

Internetes hivatkozások

I1: Az Európai Unió Hivatalos Lapja (letöltés: 2013. 10.08)

http://eur-lex.europa.eu/LexUriServ/LexUriServ.do?uri=OJ: C:2011:372:0001:0006:HU:PDF 